\title{
Optimisation of shock absorber process parameters using failure mode and effect analysis and genetic algorithm
}

\author{
Arokiasamy Mariajayaprakash ${ }^{1^{*}}$, Thiyagarajan Senthilvelan ${ }^{2}$ and Krishnapillai Ponnambal Vivekananthan ${ }^{3}$
}

\begin{abstract}
The various process parameters affecting the quality characteristics of the shock absorber during the process were identified using the Ishikawa diagram and by failure mode and effect analysis. The identified process parameters are welding process parameters (squeeze, heat control, wheel speed, and air pressure), damper sealing process parameters (load, hydraulic pressure, air pressure, and fixture height), washing process parameters (total alkalinity, temperature, pH value of rinsing water, and timing), and painting process parameters (flowability, coating thickness, pointage, and temperature). In this paper, the process parameters, namely, painting and washing process parameters, are optimized by Taguchi method. Though the defects are reasonably minimized by Taguchi method, in order to achieve zero defects during the processes, genetic algorithm technique is applied on the optimized parameters obtained by Taguchi method.
\end{abstract}

Keywords: Ishikawa diagram; FMEA; Taguchi method; Genetic algorithm

\section{Introduction}

Shock absorber is one of the major components used in automobiles. It is used to absorb vibrations when the vehicle is moving. Otherwise, those vibrations will affect the vehicle and the rider. The defects which occurred during the process affect the quality of the shock absorber. In order to minimize the defects and improve the quality, the following tools are employed. First, the cause and effect diagram or Ishikawa diagram is used for identifying the parameters that may affect the quality of the shock absorber during the process. Then, failure mode and effect analysis (FMEA) tool is applied to find out the most significant process parameters that may affect the quality of the shock absorber. Finally, Taguchi method is used to optimize the process parameters. Taguchi method is an efficient and powerful tool that can reduce the experimental trials necessary to determine the optimal conditions. It has been widely used in many different fields (Liu et al. 2010).

\footnotetext{
* Correspondence: jayaprakashrgcet@gmail.com

${ }^{1}$ Department of Mechanical Engineering, Rajiv Gandhi College of Engineering and Technology, Kirumabakkam, Puducherry 607402, India

Full list of author information is available at the end of the article
}

Tsai et al. (2008) used Taguchi's design of experiments to identify the optimal abrasive jet polishing parameters when applied to the polishing of electrical-dischargedmachined SKD 61 mold steel specimens. This paper shows that the analysis of variance (ANOVA) provides an indication of the significance of the individual control factors. Mahapatra and Chaturvedi (2009) proved that Taguchi's experimental design is a simple and systematic way of analyzing a complex process with less experimental design.

In this paper, test parameters are optimized for minimum wear by Taguchi method. Ganapathy et al. (2009) optimized the operating parameters in Jatropha biodiesel engine by Taguchi method.

In this paper, it is proved that signal-to-noise $(\mathrm{S} / \mathrm{N})$ ratio is used to optimize the various input parameters of the model. This paper shows that the Taguchi approach-based thermodynamic model has improved the performance parameters slightly. Pishbina et al. (2010) investigated the effects of processing parameters, including suspension concentration, $\mathrm{pH}$, and electric field by Taguchi's design of experiment (DOE) approach in electrophoretic deposition of bioglass suspension. Momeni 


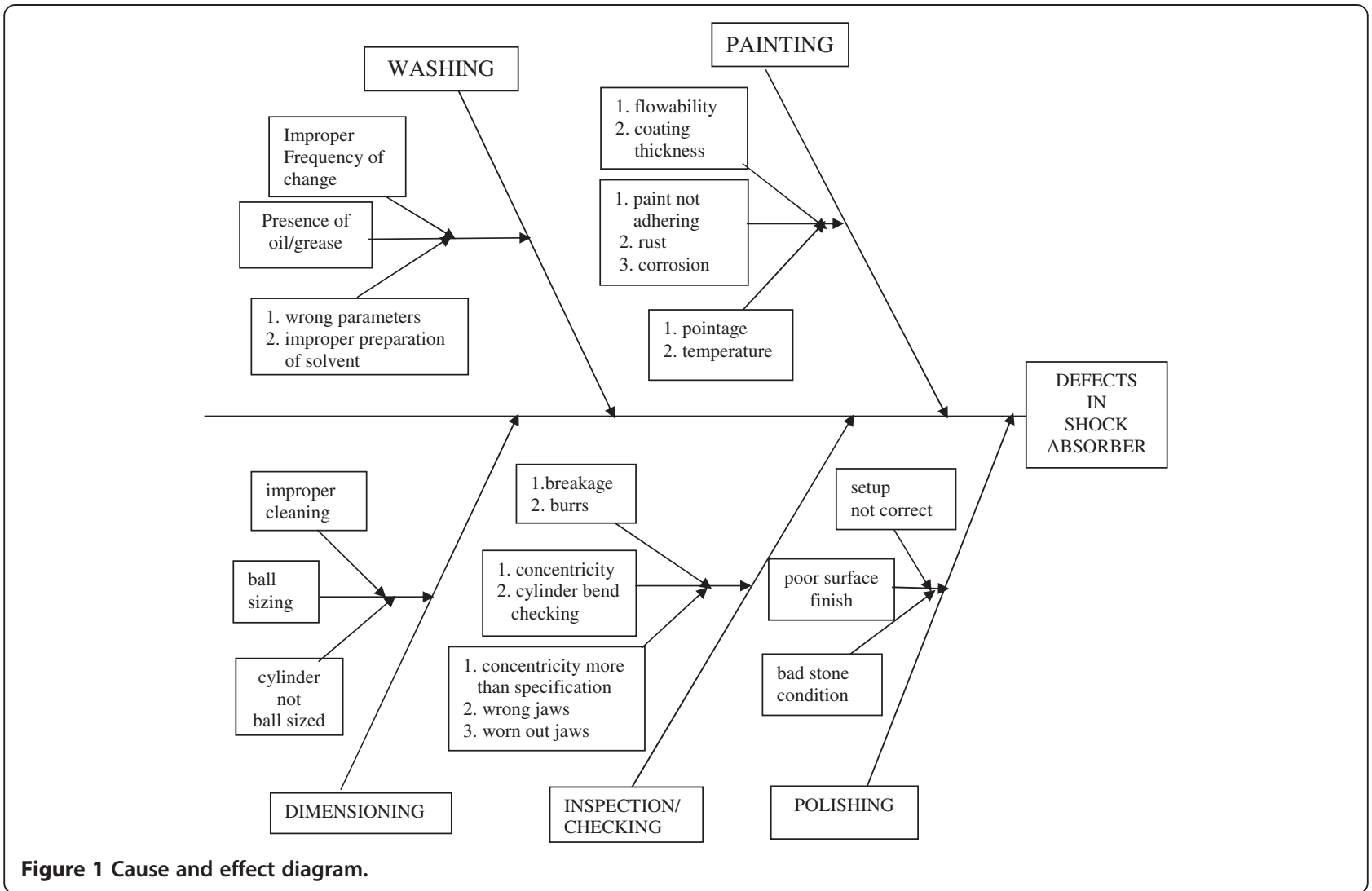

et al. (2010) obtained the optimal condition for the degree of sensitization (DOS) measurement based on double-loop EPR technique in $\mathrm{H}_{2} \mathrm{SO}_{4}$-containing $\mathrm{KSCN}$ solution by Taguchi method. In this paper, it is concluded that the higher $\mathrm{S} / \mathrm{N}$ ratio, the greater is the effect on the DOS measurement. Li et al. (2009) explained how Taguchi method is utilized for optimizing the parameters in thermal flow techniques for sub-35-nm contact-hole fabrication. In this article, the optimal thermal flow parameter settings are determined by signalto-noise ratio and ANOVA analysis. Gopalsamy et al. (2009) applied Taguchi method to find the optimum process parameters for end milling while hard machining of hardened steel. Results obtained from Taguchi method closely match with ANOVA, and it is found that

Table 1 Process parameters with their ranges and values at three levels

\begin{tabular}{cccccc}
\hline $\begin{array}{c}\text { Parameter } \\
\text { designation }\end{array}$ & $\begin{array}{c}\text { Process } \\
\text { parameters }\end{array}$ & Range & Level & Level & Level \\
\hline A & Flowability $(\mathrm{s})$ & 15 to 25 & 15 & 20 & 25 \\
\hline B & Coating thickness $(\mu \mathrm{m})$ & 20 to 50 & 20 & 40 & 50 \\
\hline C & Pointage & 6 to 12 & 6 & 8 & 12 \\
\hline D & Temperature $\left({ }^{\circ} \mathrm{C}\right)$ & 20 to 50 & 2 & 35 & 50 \\
\hline
\end{tabular}

cutting speed is the most influencing parameter corresponding to quality characteristics.

Hossain et al. (2010) illustrated that the cause and effect diagram provides the solution to reduce the emission of $\mathrm{CO}_{2}$. Andrejkovic et al. (2011) explained that the Ishikawa diagram quickly identifies the causes of quality problems. Tlale et al. (2008) applied the usage of the cause and effect diagram in cost drivers for manufacturing process. Liu et al. (2011) reported about the usage of FMEA tool and how it is applied to identify the failure modes. Arabian-Hoseynabadi et al. (2010) explained that

\section{Table 2 L9 orthogonal array}

\begin{tabular}{ccccc}
\hline Run & A & B & C & D \\
\hline 1 & 1 & 1 & 1 & 1 \\
2 & 1 & 2 & 2 & 2 \\
3 & 1 & 3 & 3 & 3 \\
4 & 2 & 1 & 2 & 3 \\
5 & 2 & 2 & 3 & 1 \\
6 & 2 & 3 & 1 & 2 \\
7 & 3 & 1 & 3 & 2 \\
8 & 3 & 2 & 1 & 3 \\
9 & 3 & 3 & 2 & 1 \\
\hline
\end{tabular}


Table 3 Experimental L9 array

\begin{tabular}{ccccc}
\hline $\begin{array}{c}\text { Trial } \\
\text { no. }\end{array}$ & $\begin{array}{c}\text { A } \\
\text { Flow } \\
\text { ability }(\mathbf{s})\end{array}$ & $\begin{array}{c}\text { B } \\
\text { Coating } \\
\text { thickness }(\boldsymbol{\mu m})\end{array}$ & $\begin{array}{c}\text { C } \\
\text { Pointage }\end{array}$ & $\begin{array}{c}\text { D } \\
\text { Temperature } \\
\left({ }^{\circ} \mathbf{C}\right)\end{array}$ \\
\hline 1 & 15 & 20 & 6 & 20 \\
\hline 2 & 15 & 40 & 8 & 35 \\
\hline 3 & 15 & 50 & 12 & 50 \\
\hline 4 & 20 & 20 & 8 & 50 \\
\hline 5 & 20 & 40 & 12 & 20 \\
\hline 6 & 20 & 50 & 6 & 35 \\
\hline 7 & 25 & 20 & 12 & 35 \\
\hline 8 & 25 & 40 & 6 & 50 \\
\hline 9 & 25 & 50 & 8 & 20 \\
\hline
\end{tabular}

the FMEA tool is applied in wind turbine systems. In this paper, the reliability of the wind turbine system is improved by applying FMEA tool. Boldrin et al. (2009) identified and reduced the risks of failure in ITER NB injector using the FMEA tool.

\section{Cause and effect diagram}

Cause and effect diagram is a tool for identifying the root causes of quality problems. It is also called as the Ishikawa diagram or fishbone diagram (Ilie and Ciocoiu 2010). The Ishikawa diagram is constructed, as shown in Figure 1. Using this diagram, the various process parameters that affect the quality of the shock absorber are identified (Sen and Shan 2005). The identified process parameters are listed below:

1. Washing parameters.

2. Welding parameters.

3. Painting parameters.

4. Damper sealing parameters.

5. Assembly parameters.

6. Lubrication parameter.

7. Inspection and checking parameters.
Table 5 Painting defects values and $\mathrm{S} / \mathrm{N}$ ratios against trial numbers

\begin{tabular}{cccccc}
\hline Trial no. & \multicolumn{4}{c}{ Defects in experiment (\%) } & \\
\cline { 2 - 5 } & $\mathbf{1}$ & $\mathbf{2}$ & $\mathbf{3}$ & Average & S/N ratio \\
\hline 1 & 4.00 & 5.00 & 5.19 & 4.73 & -13.55 \\
\hline 2 & 2.67 & 2.50 & 1.30 & 1.71 & -7.00 \\
\hline 3 & 5.33 & 5.00 & 5.19 & 5.18 & -14.28 \\
\hline 4 & 1.33 & 3.75 & 2.60 & 2.56 & -8.77 \\
\hline 5 & 2.67 & 2.50 & 2.60 & 2.59 & -8.26 \\
\hline 6 & 2.67 & 2.50 & 2.60 & 2.59 & -8.26 \\
\hline 7 & 2.67 & 2.50 & 2.60 & 2.59 & -8.26 \\
\hline 8 & 2.67 & 3.75 & 5.19 & 4.31 & -12.06 \\
\hline 9 & 4.00 & 2.50 & 2.60 & 3.03 & -9.85 \\
\hline & & & & &
\end{tabular}

8. Dimensioning parameters.

9. Polishing parameter.

10. Testing parameters.

\section{Failure mode and effect analysis}

After constructing the Ishikawa diagram, it is important to perform failure mode and effect analysis. FMEA is a powerful tool which is used to define, identify, and eliminate known potential failures, problems, errors, and so on (Liu et al. 2011). Today, FMEA technique has been applied in many places, such as automobiles, aerospace, military, electricity, and mechanical industries. Basically, FMEA can be classified into two main types: design FMEA and process FMEA. Design FMEA deals with design activities, such as product design, machine, or tooling design. It involves the steps of breaking down the product into smaller parts such as sub-assemblies, sub-systems, or components. Process FMEA is used to solve problems due to manufacturing processes. It starts with a process flow chart that shows each of the manufacturing steps of a product. The potential failure modes and potential causes for each of the process steps are identified; then, the current controls are determined,

Table 4 Defects and the number of defects that occurred during the experiments

\begin{tabular}{|c|c|c|c|c|c|c|}
\hline \multirow[t]{2}{*}{ Defects } & & & & \multicolumn{3}{|c|}{ No. of defects } \\
\hline & & & & Trial 1 & Trial 2 & Trial 3 \\
\hline Paint not adhering & Rusting & Not drying & Not cleaning & 4 & 4 & 4 \\
\hline Paint not adhering & & & & 1 & 2 & 1 \\
\hline Paint not adhering & Manual coating & Powder deposit & Over heating & 4 & 4 & 4 \\
\hline Powder deposit & Not drying & & & 2 & 2 & 2 \\
\hline Rusting & Not cleaning & & & 2 & 2 & 2 \\
\hline Paint not coming & Powder deposit & & & 2 & 2 & 2 \\
\hline Paint not coming & Rusting & Over heating & & 2 & 4 & 4 \\
\hline Paint not coming & Not drying & & & 3 & 2 & 2 \\
\hline$\overline{\text { Total }}$ & & & & 20 & 22 & 21 \\
\hline
\end{tabular}


Table 6 Average values of painting defects and S/N ratios at different levels

\begin{tabular}{|c|c|c|c|c|c|c|}
\hline \multirow[t]{2}{*}{ Factors } & \multicolumn{2}{|c|}{ Level 1} & \multicolumn{2}{|c|}{ Level 2} & \multicolumn{2}{|c|}{ Level 3} \\
\hline & Painting defects & $\mathrm{S} / \mathrm{N}$ ratios & Painting defects & $\mathrm{S} / \mathrm{N}$ ratios & Painting defects & $\mathrm{S} / \mathrm{N}$ ratios \\
\hline A & 4.02 & -11.61 & 2.58 & -8.43 & 3.16 & -10.06 \\
\hline B & 3.29 & -10.19 & 2.87 & -9.10 & 3.60 & -10.80 \\
\hline$C$ & 3.73 & -11.29 & 2.58 & -8.54 & 3.45 & -10.27 \\
\hline D & 3.45 & -10.55 & 2.45 & -7.84 & 3.87 & -11.70 \\
\hline
\end{tabular}

followed by the effects of failures on the manufacturing line operators and product end-users. The risks of these effects are then assessed accordingly. FMEA is carried out by a cross-functional team of experts from various departments FMEA is conventionally carried out by a team of engineers. Using their knowledge and past data, risk priority number (RPN) value is assigned for each failure component (Zhang and Chu 2011). RPN is the product of the occurrence (o), severity (s), and detection (d) of a failure. The three risk factors are evaluated using a ten-point scale. Failure modes with higher RPN values are assumed to be more important and are given higher priorities than those with lower RPN values (Wang et al. 2009). In this paper, washing and painting process parameters are having higher RPN values. Hence, these two process parameters are considered as the most significant process parameters.

\section{Taguchi method}

Taguchi method is an efficient tool for acquiring optimal process parameters. In this method, the number of experiments is reduced. In this method, two important tools are used: (1) orthogonal array and (2) signal-tonoise ratio (Gologlu and Sakarya 2008). First, experiment parameter factors and their levels are selected. In this study, four painting process parameters are used as control factors, and each parameter is designed to have

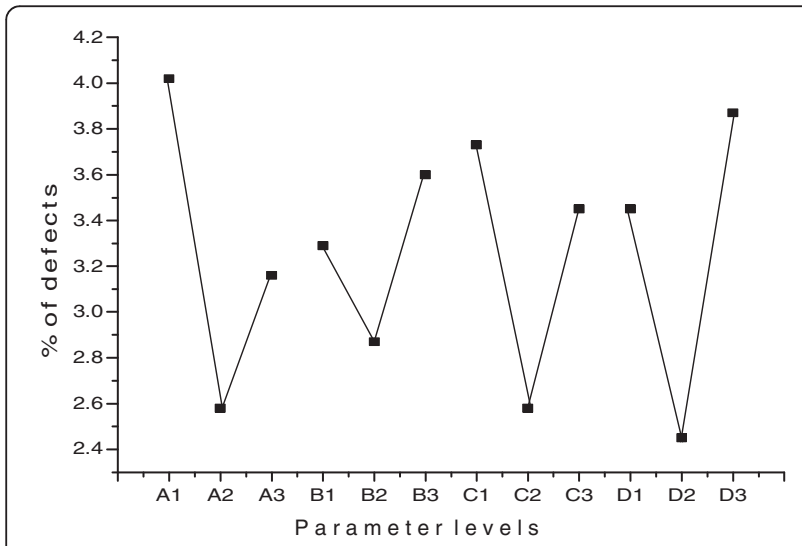

Figure 2 Average values of painting process defects for each parameter at different levels. three levels (Kilickap 2010). The selected process parameters, ranges, and their levels are shown in Table 1.

\section{Selection of orthogonal array}

An orthogonal array for process design is applied on the knowledge of control factors and levels. The number of experiments can be reduced using orthogonal array (Yen et al. 2011). The degrees of freedom for the orthogonal array should be greater than or at least equal to those for the process parameters. In this study, L9 orthogonal array having eight degrees of freedom is selected (Anawa and Olabi 2008). This orthogonal array has four columns and nine experiment runs, and it is shown in Table 2.

\section{Conducting the experiment}

After selecting the orthogonal array, the factors at different levels are assigned for each trial. The assigned experimental array is shown in Table 3. The experiments are conducted by single randomization technique. Each experiment is repeated three times for the same set off parameters (Ross 1988; Mohamed et al. 2008). In each trial, the defects occurring are recorded, and it is shown in Table 4. In this work, the defects that occur during the welding, washing, painting, and tamper sealing process are considered. The percentage of the defects for each repetition was calculated using the given formula, and then, the average of the defects was determined for each trial condition, and it was shown in Table 5.

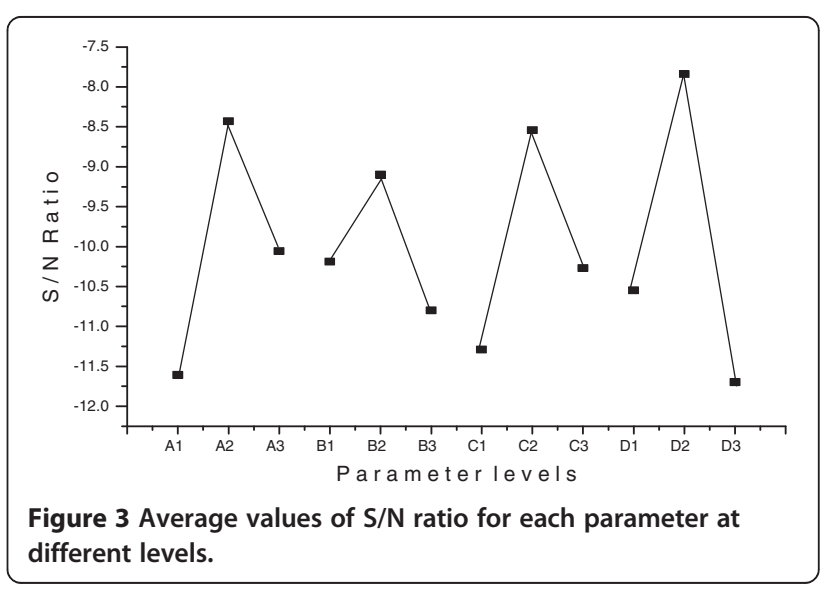


No. of defects occuring due to painting process

Percentage of defects $=\frac{\text { Total no. of defects in the process (welding, washing, painting, and Damper sealing) }}{\text { The }}$

\section{$\mathrm{S} / \mathrm{N}$ ratio}

Taguchi technique utilizes the signal-to-noise ratio approach to measure the quality characteristic deviating from the desired value. $\mathrm{S} / \mathrm{N}$ ratio is used as an objective function for optimizing parameters. (Prihandana et al. 2009). Control factors are easily adjustable, and it is set by the manufacturer. These factors are most important in determining the quality characteristics. Noise factors are difficult, impossible, or expensive to control (weather, temperature, humidity, etc.). The $\mathrm{S} / \mathrm{N}$ ratio is the ratio of mean (signal) to the standard deviation (noise). There are several $\mathrm{S} / \mathrm{N}$ ratios available depending on the type of characteristics (Mahapatra et al. 2008; Moshat et al. 2010).

(1) smaller is better

$$
\eta=-10 \log 1 / n \sum_{i=1}^{n} y_{i^{2}},
$$

(2) nominal is the best

$$
\eta=10 \log 1 / n \sum_{i=1}^{n} \mu^{2} / \sigma^{2}
$$

(3) higher is better.

$$
\eta=-10 \log 1 / n \sum_{i=1}^{n} 1 / y_{i^{2}}
$$

where, $\eta=\mathrm{S} / \mathrm{N}$ ratio, $y_{i}=$ value of quality characteristic at $i$ th setting, $\mu=$ mean, $n=$ total number of trial runs at $i$ th setting, and $\sigma=$ standard deviation.

In this study, in order to minimize the defects, smaller is better $\mathrm{S} / \mathrm{N}$ ratio is chosen. Smaller is better $\mathrm{S} / \mathrm{N}$ ratios are computed, and the values are recorded in Table 5. The main objective of shock absorber process is to minimize the defects by determining optimal level of each factor. Since - log is a monotone decreasing function, it implies that we should maximize the $\mathrm{S} / \mathrm{N}$ ratio (Shiou and Hsu 2008). The average values of the painting defects and $\mathrm{S} / \mathrm{N}$ ratios for each parameter at different levels are calculated and are recorded in Table 6.

The values given in Table 6 are plotted in Figures 2 and 3 . Figures 2 and 3 show the average values of casting defects and $\mathrm{S} / \mathrm{N}$ ratios for each parameter at different levels. From Figures 2 and 3, it is clear that the casting defects are minimum at the parameter levels A2, B2, C2, and $\mathrm{D} 2$, and the $\mathrm{S} / \mathrm{N}$ ratios are maximum at the same levels of the parameters A2, B2, C2, and D2. Since a higher $\mathrm{S} / \mathrm{N}$ ratio means a better quality characteristic (minimum defects), the optimal combination of control factor levels is therefore determined as A2 B2 C2 D2.

\section{Analysis of variance}

The purpose of ANOVA is to investigate which process parameters significantly affect the quality characteristic. The total variation may be decomposed into many components. In this paper, the total variation present in the process is decomposed to the following components:

1. variation due to factor $A$.

2. variation due to factor $B$.

3. variation due to factor $C$.

4. variation due to factor $D$.

5. variation due to error.

The total variation is calculated using the values given in Table 4.

Total variation $\mathrm{SS}_{\mathrm{T}}=\mathrm{SS}_{\mathrm{A}}+\mathrm{SS}_{\mathrm{B}}+\mathrm{SS}_{\mathrm{C}}+\mathrm{SS}_{\mathrm{D}}+\mathrm{SS}_{\mathrm{E}}$.

Variation due to error

\begin{tabular}{|c|c|c|c|c|c|c|c|c|}
\hline \multirow[t]{2}{*}{ Source } & \multicolumn{2}{|c|}{ Sum of squares } & \multicolumn{2}{|c|}{ Degrees of freedom } & \multicolumn{2}{|c|}{ Variance } & \multicolumn{2}{|c|}{$F$ ratio } \\
\hline & Painting defects & $\mathrm{S} / \mathrm{N}$ ratio & Painting defects & $\mathrm{S} / \mathrm{N}$ ratio & Painting defects & $\mathrm{S} / \mathrm{N}$ ratio & Painting defects & $\mathrm{S} / \mathrm{N}$ ratio \\
\hline A & 9.44 & 14.97 & 2 & 2 & 4.72 & 7.49 & 8.90 & 24.87 \\
\hline B & 2.40 & 4.20 & 2 & 2 & 1.20 & 2.10 & 2.26 & 6.98 \\
\hline C & 6.44 & 11.39 & 2 & 2 & 3.22 & 5.70 & 6.07 & 18.92 \\
\hline$D$ & 9.63 & 23.41 & 2 & 2 & 4.81 & 11.70 & 9.07 & 38.89 \\
\hline Error & 9.56 & 0.60 & 18 & 2 & 0.53 & 0.30 & 1.00 & 1.00 \\
\hline Total & 37.47 & 54.57 & 26 & 8 & 1.44 & 6.82 & & \\
\hline
\end{tabular}

$$
\mathrm{SS}_{\mathrm{e}}=\mathrm{SS}_{\mathrm{T}}-\left(\mathrm{SS}_{\mathrm{A}}+\mathrm{SS}_{\mathrm{B}}+\mathrm{SS}_{\mathrm{C}}+\mathrm{SS}_{\mathrm{D}}\right) .
$$

Table 7 ANOVA for painting defects and S/N ratios 
Table 8 ANOVA for painting defects, including percent contribution

\begin{tabular}{ccccccc}
\hline Source & Sum of squares & Degrees of freedom & Variance & $\boldsymbol{F}$ ratio & Expected SS & Percent contribution $(\boldsymbol{P})$ \\
\hline A & 9.44 & 2 & 4.72 & 8.90 & 6.94 & 18.52 \\
\hline B & 2.40 & 2 & 1.20 & Pooled (2.6) & & \\
\hline C & 6.44 & 2 & 3.22 & 6.07 & 6.44 & 17.19 \\
\hline D & 9.63 & 2 & 4.81 & 9.07 & 9.63 & 25.69 \\
\hline Error (pooled) & 9.56 & 18 & 0.53 & 1.00 & 14.46 & 38.60 \\
\hline Total & 37.47 & 26 & 1.44 & & 37.47 & 100.00 \\
\hline
\end{tabular}

Total degrees of freedom

$$
\begin{aligned}
v_{\mathrm{T}} & =\left(v_{\mathrm{A}}+v_{\mathrm{B}}+v_{\mathrm{C}}+v_{\mathrm{D}}+v_{\mathrm{e}}\right) \\
v_{\mathrm{e}} & =v_{\mathrm{T}}-\left(v_{\mathrm{A}}+v_{\mathrm{B}}+v_{\mathrm{C}}+v_{\mathrm{D}}\right) \\
& =26-(2+2+2+2) \\
& =18 .
\end{aligned}
$$

The results of ANOVA are shown in Table 7. In Table 7, it is clear that the parameters A, C, and D significantly affect both mean and variation in the painting defects.

Once the experiment has been conducted, the ANOVA is carried out using the results of the experiments. The significant factors and/or their interactions were identified, graphs were plotted for various trial conditions, and the parameters which significantly influence the mean and variation in the shock absorber defects were determined. However, the results obtained so far are not sufficient enough to find the optimum parameters in order to minimize the requirement of some more information to conclude with an optimum parameter set. These sets of information are obtained using the interpretation methods available in the literature (Syrcos 2002).

\section{Percent contribution}

Percent contribution is the function of the sum of squares of each significant item. Percent contribution to the total

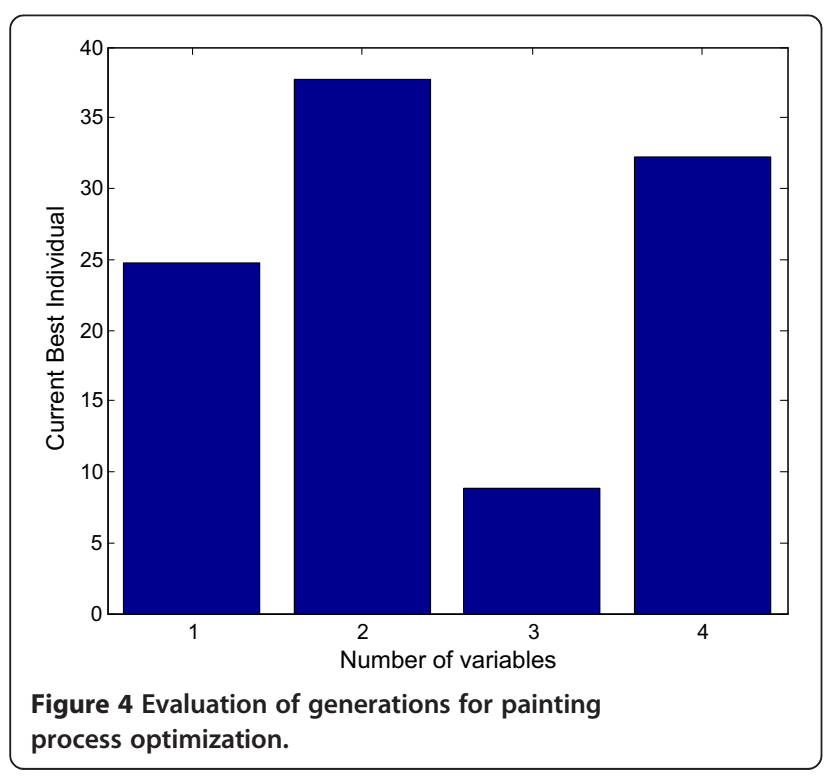

sum of square can be used to evaluate the importance of a change in the process parameter on these quality characteristics (Lakshminarayan and Balasubramanian 2008; Gopalsamy et al. 2009). It is calculated using the formulae given below:

$$
\begin{aligned}
\text { Percent contribution }(P)= & \left(\mathrm{SS}_{\mathrm{A}}^{\prime} / \mathrm{SS}_{\mathrm{T}}\right) \times 100 \\
& \mathrm{SS}_{\mathrm{A}}=\mathrm{SS}_{\mathrm{A}}-\left(v_{e}\right)\left(v_{\mathrm{A}}\right) \\
& V_{\mathrm{A}}=V_{\mathrm{A}}{ }^{\prime}+V_{\text {error }},
\end{aligned}
$$

where $V_{\mathrm{A}}^{\prime}$ is the expected amount of variation due solely to factor A given below:

$$
\begin{aligned}
& V_{\mathrm{A}}=\mathrm{SS}_{\mathrm{A}} / v_{\mathrm{A}}, \\
& V_{\mathrm{A}}^{\prime}=\mathrm{SS}_{\mathrm{A}}^{\prime} / v_{\mathrm{A}} .
\end{aligned}
$$

\section{Estimating the mean}

From Table 8, it is clear that factor B has the least effect on the quality characteristic. In order to prevent over estimation, factor B is not considered, and the estimation of mean for painting defects is calculated by the following equation ( $\mathrm{Li}$ et al. 2009):

$$
\mu=T+(A 2-T)+(C 2-T)+(D 2-T),
$$

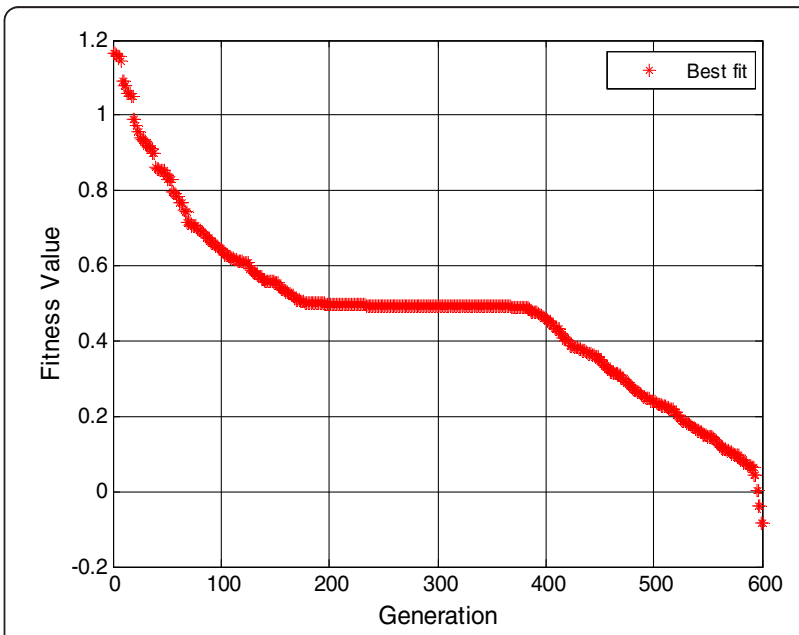

Figure 5 Best individual values obtained by GA for painting process optimisation. 
Table 9 Optimisation results obtained by Taguchi method and GA

\begin{tabular}{lccccc}
\hline & $\begin{array}{c}\text { Flow } \\
\text { ability } \\
(\mathbf{s})\end{array}$ & $\begin{array}{c}\text { Coating } \\
\text { thickness } \\
(\boldsymbol{\mu m})\end{array}$ & Pointage & $\begin{array}{c}\text { Temperature } \\
\left({ }^{\circ} \mathbf{C}\right)\end{array}$ & $\begin{array}{c}\text { Percentage } \\
\text { of defects }\end{array}$ \\
\hline $\begin{array}{c}\text { Taguchi } \\
\text { method }\end{array}$ & 20 & 40 & 8 & 35 & 0.83 \\
\hline $\begin{array}{c}\text { Genetic } \\
\text { algorithm }\end{array}$ & 24 & 40 & 8 & 31 & 0.001 \\
\hline
\end{tabular}

where $T$ is the average values of painting defects at different levels.

The mean for a selected trial condition for parameters at $\mathrm{A} 2, \mathrm{~B} 2, \mathrm{C} 2$, and $\mathrm{D} 2$ is 1.11 .

\section{Confidence interval around the estimated mean}

An important step in Taguchi's optimization technique is to conduct confirmation experiments for validating the predicted values. Thus, a 95\% confidence interval (CI) for the predicted mean of optimum quality characteristic on a confirmation test is estimated using the following two equations (Wu and $\mathrm{Gu} 2010$ ):

$$
\begin{aligned}
\mathrm{CI} 3= & {\left[F\left(\alpha, 1, v_{e}\right) V_{e}(1 / \eta \mathrm{eff}+1 / r)\right]^{1 / 2} \text { and } } \\
\eta \mathrm{eff}= & N /(1+\text { total DOF associated in the estimate } \\
& \text { of mean }),
\end{aligned}
$$

where $\alpha$ is the level of risk, $V_{\mathrm{e}}$ is the error variance, $v_{\mathrm{e}}$ is the degrees of freedom for the error, $\eta$ eff is the effective number of replications, and $r$ is number of test trials.

Using the values in Table 5, the CI was calculated as follows:

$$
\begin{aligned}
& \eta \text { eff }=N / 1+(\text { total DOF associated in the estimate of mean }) \\
& =27 /(1+2) \\
& =9 \\
& \begin{aligned}
\alpha & =1-\text { confidence limits }(95 \%) \\
& =0.05 \\
F \text { ratio } & =(1,0.05,18) \\
& =4.41(\text { tabulated }),
\end{aligned}
\end{aligned}
$$

Confidence interval CI3 $= \pm 1.02$.

The $95 \%$ confidence interval of the predicted optimum of the shock absorber defect is $0.09<1.11<2.13$.
Table 11 Washing defect values and $\mathrm{S} / \mathrm{N}$ ratio against trial numbers

\begin{tabular}{cccccc}
\hline Trial no. & \multicolumn{5}{c}{ Defects in experiment (\%) } \\
\cline { 2 - 6 } & $\mathbf{1}$ & $\mathbf{2}$ & $\mathbf{3}$ & Average & S/N ratio \\
\hline 1 & 4.00 & 2.50 & 3.90 & 3.47 & -10.96 \\
\hline 2 & 1.33 & 2.50 & 1.30 & 1.71 & -5.10 \\
\hline 3 & 2.67 & 2.50 & 2.60 & 2.59 & -8.27 \\
\hline 4 & 1.33 & 2.50 & 1.30 & 1.71 & -5.10 \\
\hline 5 & 1.33 & 1.25 & 1.30 & 1.29 & -2.24 \\
\hline 6 & 1.33 & 1.25 & 1.30 & 1.29 & -2.24 \\
\hline 7 & 1.33 & 1.25 & 1.30 & 1.29 & -2.24 \\
\hline 8 & 1.33 & 1.25 & 2.60 & 1.73 & -5.27 \\
\hline 9 & 1.33 & 3.75 & 2.60 & 2.56 & -8.77 \\
\hline
\end{tabular}

\section{Confirmation experiments}

Three confirmation experiments were conducted at the optimum setting of the process parameters. The flowability was set at the second level (A2), coating thickness at the second level (B2), wheel speed at the second level (C2), and air pressure was kept at the second level (D2). The average of the respondent defects in each experiment is found to be $0.83 \%$; the result was within the CI of the protected optimum of the casting defects. The confirming experiments results gave $0.83 \%<2.13 \%$ (maximum of CI). Therefore, the selected parameters as well as their appropriate levels are significant enough to obtain the desired result.

\section{Optimisation by genetic algorithm}

Since the conventional methods of optimization do not work well, non-traditional optimization techniques such as genetic algorithm (GA), simulated annealing, scatter search algorithm, and ant colony algorithm have been widely applied to obtain better solution in the manufacturing industries. In this research work, genetic algorithm method has been applied on the process parameters which are earlier optimized by Taguchi method in order to obtain better solution. GA is a computerized search and optimization algorithm based on the mechanics of natural genetics and natural selection (Tewari et al. 2012). Genetic algorithm is mainly composed of three operators: reproduction, crossover, and mutation. In GA, the first step is to generate initial population of individuals randomly. The individuals in the genetic space are called chromosome. A collection of genes is called as chromosome, and the

Table 10 Process parameters with their ranges and values at three levels

\begin{tabular}{cccccc}
\hline Parameter designation & Process parameters & Range & Level 1 & Level 2 & Level 3 \\
\hline A & Total alkalinity $(\mathrm{g} / \mathrm{l})$ & 40 to 80 & 40 & 70 & 80 \\
\hline B & Temperature $\left({ }^{\circ} \mathrm{C}\right)$ & 45 to 75 & 45 & 60 & 75 \\
\hline C & Rinsing water $(\mathrm{pH})$ & 5.5 to 8.5 & 5.5 & 6.5 & 8.5 \\
\hline D & Timing $(\mathrm{min})$ & 0 to 25 & 5 & 15 & 25 \\
\hline
\end{tabular}


Table 12 Average values of washing process defects and $\mathrm{S} / \mathrm{N}$ ratio at different levels

\begin{tabular}{ccccccccc}
\hline Factors & \multicolumn{2}{c}{ Level 1 } & & \multicolumn{2}{c}{ Level 2 } & & \multicolumn{2}{c}{ Level 3 } \\
\cline { 2 - 3 } & $\begin{array}{c}\text { Washing } \\
\text { defects }\end{array}$ & $\begin{array}{c}\mathbf{S} / \mathbf{N} \\
\text { ratios }\end{array}$ & $\begin{array}{c}\text { Washing } \\
\text { defects }\end{array}$ & $\begin{array}{c}\mathbf{S} / \mathbf{N} \\
\text { ratios }\end{array}$ & $\begin{array}{c}\text { Washing } \\
\text { defects }\end{array}$ & $\begin{array}{c}\mathbf{S} / \mathbf{N} \\
\text { ratios }\end{array}$ \\
\hline $\mathrm{A}$ & 2.59 & -8.11 & 1.43 & -3.19 & & 1.86 & -5.43 \\
\hline $\mathrm{B}$ & 2.16 & -6.10 & 1.58 & -4.20 & 2.15 & -6.43 \\
\hline $\mathrm{C}$ & 2.16 & -6.16 & 2.00 & -6.32 & & 1.73 & -4.25 \\
\hline $\mathrm{D}$ & 2.44 & -7.32 & 1.43 & -3.19 & 2.00 & -6.21 \\
\hline
\end{tabular}

chromosome potential is called its fitness function, which is evaluated by the objective function. In the selection process, low fitness chromosomes are eliminated using high-fitness chromosomes (Hafshejani et al. 2012). However, selection alone does not produce any new individuals into the population. Hence, cross over and mutation operations are involved. Crossover is the process for exchanging genes between two chromosomes using the one-point crossover, two-point crossover, or homologue crossover. In mutation, the genes may occasionally be altered, i.e., in binary code genes changing genes code from 0 to 1 or vice versa. The new population generated undergoes the further selection, crossover, and mutation till the termination criterion is not satisfied.

In this research work, through the application of MINITAB and based on Taguchi's orthogonal array, a mathematical model has been developed. The model has been used as objective function in the genetic algorithm. The objective function and constraints of the painting process are defined as follows:

$$
Y=3.72-0.095 A+0.0057 B-0.2123 C+0.0018 D .
$$

Minimize: $Y(A, B, C, D)$.

Constraints:

- Bounds on flowability (s): $15 \leq A \leq 25$.

- Bounds on coating thickness ( $\mu \mathrm{m}): 35 \leq B \leq 45$.

- Bounds on pointage: $6 \leq C \leq 10$.

- Bounds on temperature $\left({ }^{\circ} \mathrm{C}\right): 30 \leq D \leq 40$.

The problem of genetic algorithm has been solved using MATLAB. The parameters used in GA are population

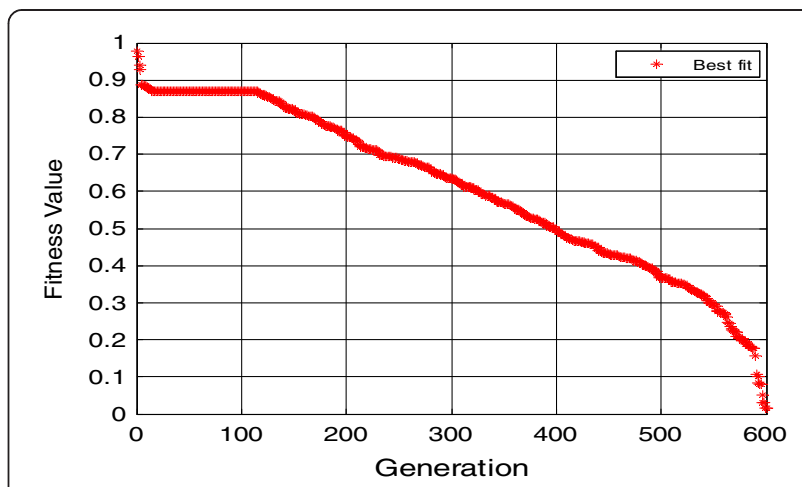

Figure 6 Evaluation of generations for washing process optimization.

size - 100, cross over probability - 0.9 , mutation probability - 0.1 and the number of generations - 600 . The evaluation of generations and the best values obtained by GA are shown in Figures 4 and 5 . Confirmation experiments have been conducted using the optimized parameters. It has been observed that the percentage of defects during the painting process is better than Taguchi method.

\section{Results and discussion}

The shock absorber experiments have been conducted, and subsequently, ANOVA is carried out using the results obtained from the experiments. Nevertheless, interpretation methods are used to obtain the percent contribution of each parameter and optimum levels of each parameter, and GA technique is applied on the parameters which have been optimized by Taguchi method:

1. The percent contribution of each parameter to the variation of painting defects and optimum parameter (under economic condition) is shown in Table 8.

2. The optimum levels of various parameters for minimum painting defects of shock absorber obtained by Taguchi method and genetic algorithm are shown in Table 9.

3. The predicted range of optimum painting defects is $0.09<1.11<2.13$.

Table $13 \mathrm{~S} / \mathrm{N}$ ratios for washing process defects, including percent contribution

\begin{tabular}{|c|c|c|c|c|c|c|}
\hline Source & Sum of squares & Degrees of freedom & Variance & $F$ ratio & Expected SS' & Percent contribution $(P)$ \\
\hline A & 36.25 & 2.00 & 18.13 & 112.84 & 35.93 & 33.20 \\
\hline B & 8.54 & 2.00 & 4.27 & 26.58 & 8.22 & 7.59 \\
\hline $\mathrm{C}$ & 7.85 & & & & & \\
\hline D & 27.30 & 2.00 & 13.65 & 84.97 & 26.98 & 24.93 \\
\hline Error (pooled) & 0.32 & 2.00 & 0.16 & 1.00 & 37.10 & 34.28 \\
\hline Total & 80.26 & 8.00 & 36.21 & 225.39 & 108.23 & 100.00 \\
\hline
\end{tabular}




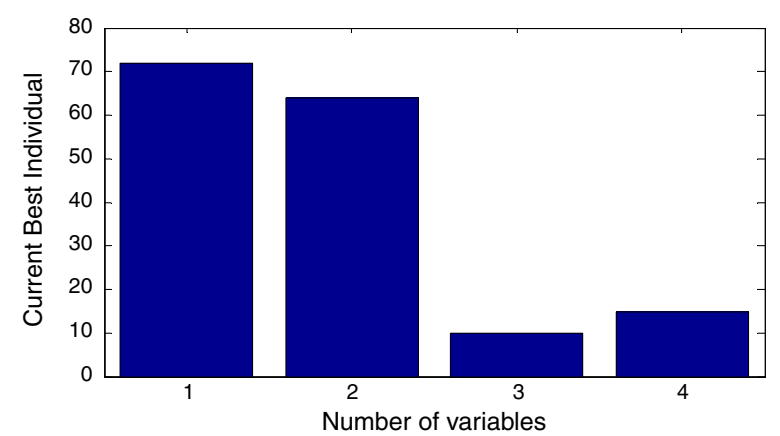

Figure 7 Best individual values obtained by GA for washing process optimisation.

In the same manner, calculations are carried out, and optimum values are found for washing process (Tables 10, 11,12 , and 13).

The mean for a selected trial condition for parameters at $\mathrm{A} 2, \mathrm{~B} 2, \mathrm{C} 3$, and $\mathrm{D} 2$ is 0.90 .

The 95\% confidence interval of the predicted optimum of the shock absorber defect is $0.13<0.90<1.67$

Furthermore, to optimize the results of washing process, GA technique has been applied using the objective function and constraints as given below:

$$
Y=4.73-0.034 A-0.012 B-0.110 C-0.0248 D .
$$

Minimize: $Y(A, B, C, D)$.

Constraints:

- Bounds on total alkalinity (g/l): $65 \leq A \leq 75$.

- Bounds on temperature $\left({ }^{\circ} \mathrm{C}\right): 55 \leq B \leq 65$.

- Bounds on $\mathrm{pH}$ value of rinsing water: $6 \leq C \leq 10$.

- Bounds on timing (s): $5 \leq D \leq 15$.

The evaluation of generations and the best values obtained by GA for washing process are shown in Figures 6 and 7. The optimized parameters obtained by Taguchi method and GA are shown in Table 14.

From the abovementioned analysis, it is observed that the percentage of defects drastically reduced after applying genetic algorithm technique in both painting and washing processes.

Table 14 Optimisation results obtained by Taguchi method and GA

\begin{tabular}{lccccc}
\hline & $\begin{array}{c}\text { Total } \\
\text { alkalinity } \\
(\mathbf{g} / \mathbf{l})\end{array}$ & $\begin{array}{c}\text { Temperature } \\
\left({ }^{\circ} \mathbf{C}\right)\end{array}$ & $\begin{array}{c}\text { Rinsing } \\
\text { water } \\
(\mathbf{p H})\end{array}$ & $\begin{array}{c}\text { Timing } \\
\mathbf{( s )}\end{array}$ & $\begin{array}{c}\text { Percentage } \\
\text { of defects }\end{array}$ \\
\hline $\begin{array}{l}\text { Taguchi } \\
\text { method }\end{array}$ & 70 & 60 & 7.5 & 10 & 1 \\
\hline $\begin{array}{l}\text { Genetic } \\
\text { algorithm }\end{array}$ & 72 & 64 & 10 & 13 & 0.004 \\
\hline
\end{tabular}

\section{Conclusions}

While the Taguchi method is an effective technique to achieve the optimum process parameters of shock absorber, the genetic algorithm technique, however, gives better solutions than Taguchi method to achieve the optimum process parameters of shock absorber. From the present study, the following results have been arrived.

1. Ishikawa diagram or cause and effect diagram is very effective to sort out all the possible causes affecting the quality of shock absorber.

2. Conventional FMEA has been applied to identify the most significant parameters (painting and washing processes) affecting the quality of the shock absorber.

3. It has been observed that the parameters pointage (painting) and timing (washing) significantly affect the quality of the shock absorber, which can be confirmed with the help of percent contribution.

4. The optimum range of the shock absorber defects has been predicted by the $95 \%$ confidence interval. The optimum range of painting process is $0.09<1.02<2.13$ and washing process is $0.13<0.90<1.67$.

5. The optimum levels of flowability, coating thickness, pointage, and temperature for painting process and total alkalinity, temperature, $\mathrm{PH}$ value of rinsing water, and timing for washing process were estimated.

6. The percentage of painting defects and washing defects obtained by Taguchi method are 0.83 and 1, respectively. After applying the genetic algorithm technique, the percentage of painting defects and washing defects had been drastically reduced to 0.001 and 0.004 , respectively.

\section{Abbreviations}

$a$ : Level of risk; $\mu$ : Mean; $\eta$ eff: Effective number of replications; ANOVA: Analysis of variance; Cl: Confidence interval; DOE: Design of experiments; $F\left(a, 1, v_{\mathrm{e}}\right)$ : $F$ ratio required at the level of risk; $k_{\mathrm{A}}$ : Number of levels for factor $A ; M$ : Overall mean percentage defects; $n$ : Total number of experiments; N: Number of trials; P: Percent contribution; $r$ : Number of tests in a trial; SS: Sum of square; T: Average values of defects at different levels; $v$ : Degrees of freedom; $v_{\mathrm{A}}$ : Degrees of freedom for factor $A ; v_{\mathrm{e}}$ : Degrees of freedom for the error; $V_{\llcorner N}$ : Total degrees of freedom of the available orthogonal array; $v_{\text {required: }}$ Total degrees of freedom required; $V$ : Expected amount of variation; $V_{e}$ : Error variance; $V_{\text {factor }}$ : Variance of factor; $y_{i}$ : Response value of observation in the ith test.

\section{Competing interests}

The authors declare that they have no competing interests.

\section{Authors' contributions}

AMJP carried out the literature study reviews, design, and experimental work. TSV worked on the computations. KPV helped to perform the experimental work. All authors read and approved the final manuscript. 


\section{Acknowledgments}

The authors would like to thank the editor and anonymous reviewers for their valuable and constructive comments, which have led to a significant improvement in the manuscript.

\section{Author details}

${ }^{1}$ Department of Mechanical Engineering, Rajiv Gandhi College of Engineering and Technology, Kirumabakkam, Puducherry 607402, India. ${ }^{2}$ Department of Mechanical Engineering, Pondicherry Engineering College, Pillaichavady, Puducherry 605014, India. ${ }^{3}$ TENNECO Automotive India private Limited, Mettupalayam, Puducherry 605009, India.

Received: 23 June 2012 Accepted: 7 May 2013

Published: 15 July 2013

\section{References}

Anawa EM, Olabi AG (2008) Using Taguchi method to optimize welding pool of dissimilar laser welded components. Optics \& Laser Technology 40(2):379-388

Andrejkovic M, Hajduova L, Mixtaj E, Weiss R (2011) Improvement of processes in metallurgy company. Metalurgija 50(2):141-144

Arabian-Hoseynabadi H, Oraee H, Tavner PJ (2010) Failure modes and effects analysis (FMEA) for wind turbines. Elect Power and Energy Syst 32:817-824

Boldrin M, De Lorenzi A, Fiorentin A, Marcuzzi D, Peruzzo S, Pomaro N, Rigato W, Serianni G (2009) Potential failure mode and effects analysis for the ITER NB injector. Fusion Eng and Design 84:466-469

Ganapathy T, Murugesan K, Gakkhar RP (2009) Performance optimization of Jatropha bio diesel engine model using Taguchi approach. Appl Energy 86(11):2476-2486

Gologlu C, Sakarya N (2008) The effects of cutter path strategies on surface roughness of pocket milling of 1.2738 steel based on Taguchi method. J Mater Process Technol 206(1-3):7-15

Gopalsamy BM, Mondal B, Ghosh S (2009) Taguchi method and ANOVA: an approach for process parameters optimization of hard machining while machining hardened steel. J Sci Ind Res 68(8):686-695

Hafshejani KF, Valmohammadi C, Khakpoor A (2012) Retracted: using genetic algorithm approach to solve a multi-product EPQ model with defective items, rework, and constrained space. J Ind Eng Int 8(27):1-7

Hossain KA, Khan F, Hawboldt K (2010) Susdesign - an approach for a sustainable process system design and its application to a thermal power plant. Appl Thermal Energy 30(14-15):1896-1913

Ilie G, Ciocoiu CN (2010) Application of fishbone diagram to determine the risk of an event with multiple causes. Manag Res Pract 2(1):1-20

Kilickap E (2010) Optimization of cutting parameters on delamination based on Taguchi method during drilling of GFRP composite. Expert Syst Appl 37(8):6116-6122

Lakshminarayanan AK, Balasubramanian V (2008) Process parameters optimisation for friction stir welding of RDE- 40 aluminium alloy using Taguchi technique. Trans Non-ferrous Metals Soc China 18(3):548-554

Li TS, Chen SH, Chen HL (2009) Thermal-flow techniques for sub-35 nm contact-hole fabrication using Taguchi method in electron-beam lithography. Microelectron Eng 86:2170-2175

Liu Y-T, Changa W-C, Yamagata Y (2010) A study on optimal compensation cutting for an aspheric surface using the Taguchi method. CIRP J Manuf Sci Technol 3(1):40-48

Liu H-C, Liu L, Bian Q-H, Lin Q-L, Dong N, Peng Cheng X (2011) Failure mode and effects analysis using fuzzy evidential reasoning approach and grey theory. Expert Syst Appl 3(8):4403-4415

Mahapatra SS, Chaturvedi V (2009) Modelling and analysis of abrasive wear performance of composites using Taguchi approach. Int J Eng Sci Technol 1(1):123-135

Mahapatra SS, Patnaik A, Satapathy A (2008) Taguchi method applied to parametric appraisal of erosion behavior of GF-reinforced polyester composites. Wear 265(1-2):214-222

Mohamed H, Hisyam Lee M, Sarahintu M, Salleh S, Sanugi B (2008) Identifying factors affecting data delivery performance in mobile ad-hoc network routing protocol using a systematic approach. Matematika 24(1):43-51

Momeni M, Moayed MH, Davoodi A (2010) Tuning DOS measuring parameters based on double-loop EPR in $\mathrm{H} 2 \mathrm{SO} 4$ containing KSCN by Taguchi method. Corros Sci 52(8):2653-2660
Moshat S, Datta S, Bandyopadhyay A, Pal P (2010) Optimization of CNC end milling process parameters using PCA-based Taguchi method. Int J Eng Sci Technol 2(1):92-102

Pishbina F, Simchi A, Ryana MP, Boccaccini AR (2010) A study of the electrophoretic deposition of Bioglass ${ }^{\circledR}$ suspensions using the Taguchi experimental design approach. J Eur Ceramic Soc 30(14):2963-2970

Prihandana GS, Mahardika M, Hamdi M, Wong YS, Kimiyuki M (2009) Effect of micro-powder suspension and ultrasonic vibration of dielectric fluid in micro-EDM Processes -Taguchi approach. Int J Mach Tools Manuf 49(12-13):1035-1041

Ross PJ (1988) Taguchi techniques for quality engineering. McGraw Hill, New York

Sen M, Shan HS (2005) Analysis of hole quality characteristics in the electro jet drilling process. Int J Mach Tools Manuf 45(15):1706-1716

Shiou FJ, Hsu CC (2008) Surface finishing of hardened and tempered stainless tool steel using sequential ball grinding, ball burnishing and ball polishing processes on a machining centre. J Mat Process Tech 205(1-3):249-258

Syrcos GP (2002) Die casting process optimization using Taguchi methods. Mater Process Technol 135:68-74

Tewari PC, Khanduja R, Gupta M (2012) Performance enhancement for crystallization unit of a sugar plant using genetic algorithm technique. $J$ Ind Eng Int 8(1):1-7

Tlale NS, Steyn JL, Govender S (2008) Technical cost modelling for a novel semi-solid metal (SSM) casting processes for automotive component manufacturing. In: International Association for Management of Technology Nice, pp 1-20. 17-19 September 2008

Tsai FC, Yan BH, Kuan CY, Huang FY (2008) A Taguchi and experimental investigation into the optimal processing conditions for the abrasive jet polishing of SKD61 mold steel. Int J Mach Tools Manuf 48(7-8):932-945

Wang Y-M, Chin K-S, Poon GKK, Yang J-B (2009) Risk evaluation in failure mode and effects analysis using fuzzy weighted geometric mean. Expert Syst Appl 36(2):1195-1207

Wu H-W, Gu HW (2010) Analysis of operating parameters considering flow orientation for the performance of a proton exchange membrane fuel cell using the Taguchi method. J Power Sources 95(11):3621-3630

Yen Y-T, Fang T-H, Lin Y-C (2011) Optimization of screen-printing parameters of SN9000 ink for pinholes using Taguchi method in chip on film packaging. Robotics Comput Integrated Manuf 27(3):531-537

Zhang Z, Chu X (2011) Risk prioritization in failure mode and effects analysis under uncertainty. Expert Syst Appl 38(1):206-214

\section{doi:10.1186/2251-712X-9-18}

Cite this article as: Mariajayaprakash et al: Optimisation of shock absorber process parameters using failure mode and effect analysis and genetic algorithm. Journal of Industrial Engineering International 2013 9:18.

\section{Submit your manuscript to a SpringerOpen ${ }^{\circ}$ journal and benefit from:}

- Convenient online submission

- Rigorous peer review

- Immediate publication on acceptance

- Open access: articles freely available online

- High visibility within the field

- Retaining the copyright to your article

Submit your next manuscript at springeropen.com 